\title{
RELEVANCE OF KEYNES \\ FOR DEVELOPING COUNTRIES
}

\author{
H. W. Singer $\left(^{*}\right)$
}

\section{Relevance of Keynes for Developing Countries}

I wish to dedicate this paper to Dudley Seers whose essay on "The Limitations of the Special Case" (1) has been one of my chief sources of guidance. His death a few months ago was a great loss. 1 also wish to acknowledge my indebtedness to Albert Hirschman $\left({ }^{2}\right)$ whose essay on "The Rise and Decline of Development Economics" has provided me with the starting point, and much more, for my own paper. Thirdly, I have of course learned a great deal from the 1952 Pioneer Paper by V. K. R. V. RAO in the Indian Economic Review on ulnvestment, Income and the Multiplier in an Underdeveloped Economyn $\left({ }^{3}\right)$ and from many discussions with him on this subject.

Albert Hirschman credits Keynes with the major methodological step in establishing the analysis of problems of developing countries on a firm scientific footing which he dates from some 35 years ago. That step was - in his own terminology - to move away from mono-economics to the proposition that different laws and rules apply to economics which find themselves in different situations. In the case of Keynes, the distinction of course was between an economy in full employment and an economy with unemployment for which he described the laws and rules in 1936 in The General Theory of Interest and Money. By contrast, the preceding classical and neo-classical economists assumed that the laws and rules of economics had universal validity, comparable to physical laws such as the law of gravity. The question immediately arose whether the Keynesian model of the General Theory was more relevant for the analysis of problems of developing countries than the classical model. There were

(*) Institute of Development Studies at the University of Sussex.

(1) SEERS, D. - "The Limitations of the Special Case", contribution to The Teaching of Development Economics, editors Kurt Martin and John Napp, Frank Cass, London, 1967.

(2) HIRSCHMAN, A. O. - "The Rise and Decline of Development Economics", contribution to The Theory and Experience of Economic Development: Essays in Honor of Sir W. Arthur Lewis, editors Gersovitz, M. et al., Allen and Unwin, London and Boston, 1982.

(3) RAO, V.K. R. V. - unvestment Income and the Multiplier in an Underdeveloped Economy", The Indian Economic Review, February 1952. 
a number of fairly obvious features which made a positive answer to this question at least superficially plausible. Such features included the following:

1) The assumption of unemployed resources seem to correspond directly to the existence of surplus labour, unemployment, disguised unemployment, under-employment, low productivity employment, the informal sectors, etc., in developing countries. However, this superficially attractive feature of the Keynesian model turned out quite soon to be rather doubtful. Of this more later;

2) The General Theory established a situation of low-level equilibrium in which market forces left to themselves would be unable to break the vicious circle. This situation of market failure required some external agency to intervene and change the situation so that forces moving to a higher-level equilibrium could be set in motion. Moreover the General Theory showed that such intervention could be self-financing, and that in fact it would constitute a positive-sum game for the economy as a whole. This again seemed to correspond to the situation in developing countries where market failures, interventionist policies and government planning rapidly became familiar and almost universally accepted concepts;

3) A related feature of the General Theory model as distinct from the classical model which also seemed to make it directly more relevant to developing countries is that the emphasis is on the mobilisation of resources and not only on the allocation of resources. Moreover, the mobilisation of resources in the Keynesian model takes place mainly through additional investment, with its associated multiplier and accelerator effects; this is most clearly expressed in the Harrod-Domar model derived from Keynesian analysis. The Harrod-Domar model soon became the cornerstone of much of the policies and development planning of developing countries in the early post-war years;

4) Just as in the developing countries so also in the Keynesian system the objective of the analysis is how to change an unsatisfactory initial condition, where as in the classical system the emphasis was on understanding the system, not on changing things. This is related to a feature of Keynes' thinking and reasoning on which all commentators and biographers agree, i.e. that his main interest was in policies rather than theories. This is agreed for example by Hayek, Friedman and Samuelson in their respective contributions on the Keynes Centenary in the series recently published in The Economist. Hayek mentions this reproachfully and critically, saying that Keynes did not 
"think much of economics as a science" and used his interest in policies in a Machiavellian way to bend "science" to his own policy preferences ( «tending to regard his superior capacity for providing theoretical justifications as a legitimate tool for persuading the public to pursue the policies which his intuition told him were required at the moment»). By contrast SamueIson mentions his preference for policies rather than theory with approval, while Friedman mentions it more neutrally: "Though Keynes was a great theorist, his interest in theory was not for its own sake but as a basis for designing policy" $\left({ }^{4}\right)$. However, whether a vice a la Hayek or a virtue a la Samuelson, either way the preference for policy-making over theorising is undisputed and it is this feature of Keynes and his work which appeals to those concerned with the problem of developing countries. This point is related to what Hirschman $\left({ }^{5}\right)$ mentions as the second characteristic of the nascent development economics, apart from the abandonment of mono-economics, i.e. that it had an appeal - particularly to liberal welfare-oriented economics, in the Anglo-Saxon tradition-- in opening the possibility of improving things and playing positive-sum games (of which more later);

5) The General Theory has a streak of "national self-sufficiency" - Hayek $\left({ }^{6}\right)$ draws attention to the essay which Keynes had published under the same title in The New Statesman and Nation in 1933. This can presumably be attributed to the collapse of the 1933 World Economic Conference in London and the necessity - as Keynes saw it- for "going it alone". Also, the large size at the time of the British economy in relation to the global economy made such a policy plausible and kept the import and balance of payments problems involved at the level of manageable "leakages" (especially since Keynes was quite ready to contemplate flexible exchange rates). This seemed to many people in developing countries to have a family resemblance to their desire for greater national autonomy and "self-reliancen, national or collective. It also seemed to suit the conditions of India well, although Rao (7) questions this statement even for India, foreshadowing a long line of criticism of

(4) FRIEDMAN, M. - «A Monetarist Reflects", The Economist, 4 June 1983, pp. 35-37; HAYEK, F. A. - "The Austrian Critique», The Economist, 11 June 1983, pp. 45-48; SAMUELSON, P. - "Sympathy from the Other Cambridge", The Economist, 25 June 1983, pp. 21-25. These contributions to The Economist appeared in a series "The Keynes Centenary".

(5) Loc. cit.

(6) Loc. cit.

(7) Loc. cit. 
Keynesian policies being incompatible with the balance of payments position of LDCs and specifically with the dependence of investment on imported inputs; import bottlenecks would set an abrupt end to the working of the multiplier, or in Harrod-Domar terms would increase the capital/output ratio sharply.

Having blasted a trail for a duo-economics model by distinguishing between full employment and unemployment economies, Keynes has been followed by an influential other duo-economics model, i.e. a model distinguishing between centre an periphery economies. This model developed particularly by Prebisch and Seers has been instrumental in the development of the dependency school. It was also inherent in the Prebisch-Singer hypothesis of a different position of primary commodities and manufactured goods (or alternatively of technologically developed and technologically underdeveloped countries) in world trade. In a sense both Keynes and Prebisch-Seers were preceded by the duo-economics models by List and Hamilton distinguishing between industrial pioneers (the UK) and industrial latecomers (Germany, USA). The Lewis distinction between economies with limited and unlimited supplies of Labour, superficially closest to the Keynesian model, could also be listed as a duoeconomics model.

However, it was also soon evident that the General Theory, in spite of its title, in fact still described a very Special Case - in the sense of Dudley Seers. That Special Case was that of an advanced industrial country - or perhaps even more specifically that of England in the mid-thirties - with all the specific features and assumptions (often more implied and taken for granted than specifically mentioned) of this particular economy and society, conspicuously different from those of any developing country. Rao $\left({ }^{8}\right)$ for example lists four such assumptions:

a) Involuntary unemployment;

b) An industrialized economy where the supply curve of output slopes upwards towards the right but does not become vertical till after a substantial interval;

c) Excess capacity in the consumption-goods industries;

d) Comparatively elastic supply of the working capital required for increased output.

Rao then goes on to dispute the validity of these assumptions for India, and thus to question the relevance and validity of the basic concepts of the General Theory for developing countries. Dudley Seers also specifically criticises the misleading nature of the General Theory.

(8) Loc. cit. 
The four assumptions listed by Rao are by no means a complete list. One could add other important items, such as the availability of data for pursuing Keynesian policies, the existence of a trained and experienced civil service to manage macro-economic policies, organize public investment etc., the existence of a well-established direct taxation system which would help to prevent inflationary consequences of budget deficits and which would make such deficits "self-financing" as a result of the increased government revenue associated with higher levels of output and employment etc. In fact we are coming back here to the point that the General Theory is really based on the model of the British economy; referring once again to The Economist series on "The Keynes Centenary", Hayek once again disapprovingly refers to Keynes being "a great patriot, if that is the right word for a profound believer in the superiority of British civilization" $\left({ }^{9}\right)$; while Samuelson (in this case equally disapprovingly) after also noting that Keynes was "a British patriot» refers to his «insular background" and calls him "the most provincial of British patriots", paradoxically combined with his cosmopolitanism $\left({ }^{10}\right)$.

If the General Theory is based on the special case of the British economy, the question arises of whether a model of the typical economy of an underdeveloped country can be substituted for the Keynesian model. Rao's four items are presumably an attempt to sketch the main features of such an economy which indeed he proceeds to do in more detail in his article for the case of India, emphasising the different nature of unemployment in an agrarian economy with a prevailing mode of household production (as India then was), the supply bottlenecks which make the supply curve of output become vertical at a much earlier point than in the Keynes state of full employment; the absence of excess capacity in the consumption industries; the absence of an organized working system of supplying the working capital required for increased output, etc. These are probably features which in some degree or other are common to developing countries - but are they sufficient to establish an alternative model? Dudley Seers clearly believed that they are not: he would argue that there have to be separate special cases for large and small economies (say India versus Mauritius); for economies in different stages of development (say Korea versus Afghanistan); for oil exporters versus oil importers (say Saudi Arabia versus the Sudan); for centrally-planned versus market-orientated economies (say Tanzania versus Senegal) or more generally for economies exporting manufactured goods versus primary exporters (Singa-

(9) Loc. cit.

(10) Loc. cit., p. 22, but Samuelson's sole explicit evidence for calling Keynes «the most provincial of British patriots" is that "he never really cared for Americans". Is not this perhaps an example of American provincialism? 
pore versus Zambia) or even specifically for economies according to the nature of their main export (copper exporting countries, coffee exporting countries, etc.). Thus, there would be no single alternative non-Keynesian model, but a series, perhaps a large number, of such models. This is indeed "abandonment of mono-economics" with a vengeance. Taken to its logical conclusion, this would amount to the position that in the analysis of developing countries there is no place for a "model" approach, but that each country must be studied on its own and in the light of its own conditions. A model which is good for all countries is good for no country (11). Thus there is no scope for any expertise other than knowledge of field conditions, and perhaps the formal expertise of how to collect and organize data, how to present conclusions and policy recommendations, etc.

Technically the situation in developing countries can be described as a matter of lower supply elasticities. But the difference really goes deeper than that. It is fundamental enough to make it doubtful whether the same intellectual apparatus can cover both situations. The market as an operating institution and structure does not really exist in many developing countries in the same sense in which it could be taken for granted in the UK of the 1930s which was the background of the General Theory. This applies not only to commodity markets but also to factor markets, money markets, government responses etc., indeed the whole structure of society is such that "indicative planning" of the Keynesian type is neither sufficient nor possible. While the prevailing shortages of foreign exchange intensify such difficulties on the supply side, they would apply even, say, to OPEC countries. The assumption that expanded demand, whether government or private, will be effective in solving employment, growth and poverty problems will not be tenable. Once again, one could perhaps technically say that this is only a matter of degree, i.e. that provided the expansion of demand is large enough at one point it should be able to move supply. But this would be at the expense of enormous inflation and could not be the basis of sustainable growth. In any case, the only safe assumption is that supply curves become vertical very early in this process. Hence any realistic model for developing countries must be one which starts off with the supply side rather than the demand side(12).

In the General Theory, and even more so in the national accounting system and the Harrod-Domar growth model based on Keynesian concepts, investment is identified with production of physical goods different

(11) Michal Kalecki took the same position in "Theories of Growth of Different Social Systems", Scientia (Italy), May-June 1970. (I am indebted to Jerzy Osiatynsky for pointing this out to me.)

(12) This point is clearly argued by Michael P. Todaro, Economic Development in the Third World, Longman, London and New York, 1977, pp. 177-179. 
in nature from consumption goods. These goods by a combination of marginal productivity, multipliers and accelerators produce subsequent income and create immediate employment; on both grounds they are particularly desirable in poor economies with unemployed resources. For developing countries, however, this is a very narrow concept of investment and one which may seriously mislead policy-makers.

The point is that developmental investment is to a large extent - perhaps to a dominant extent - investment in human resources or in public services such as health and education. Quantitative studies have invariably shown the great importance of such "human investment" as distinct from the production of physical investment goods emphasised by Keynes. Keynes was of course fully entitled, in a country like the UK, to assume away the importance of such human investment - further human investment would have come rightly under the heading of consumption or welfare rather than investment. But in developing countries it would be wrong to disregard human investment. While it is true that human investment also has some kind of physical element - the construction of hospitals, schools, production of school books, etc. - that clearly is not the essence of the matter.

The Harrod-Domar growth model based on the Keynesian analysis underlines the identification of investment with the production of capital goods. Now it is true that in the Harrod-Domar model allowance can be made for human investment not based on the production of goods through the capital/output ratio by which the rate of investment has to be divided in order to obtain the rate of growth. However, the enumerator (capital investment) has much higher visibility than the denominator (the capital/output ratio which is not specifically and visibly identified with human investment). This can and in fact has misled development planners using the Harrod-Domar formula to overrate the importance of physical investment and to underrate that of human investment. The corollary has been that in times of financial stringency it was human investment which was cut down at the expense of capital investment( ${ }^{13}$ ).

(13) The point made in the preceding three paragraphs is also made by Andrew $M$. Kamarck, Economics and the Real World, Blackwell, 1983, pp. 108-115. Kamarck writes: "The present situation, in which economists spend their time measuring what is easy to measure (durable capital goods) instead of trying to measure what is less precise but what really matters, is like the story of the drunk who had lost some money. He hunted for it under a street light because the light was better, rather than looking for it in the dark alley where he had really lost it. If economists truly want to be useful, we have to look where the problems are, and not where it is easiest to look.» For the same criticism of the Harrod-Domar formula see also H.W. Singer, "Keynesian Models of Economic Development and their Limitations: an Analysis in the Light of Gunnar Myrdal's 'Asian Drama'"; in The Strategy of International Development, Macmillan, 1975. 
The reasons why investment in developing countries will not be able to rise as much as or as predictably in response to increased aggregate demand or increased profitability can be summarized as follows:

1) The technological capacity to produce the required investment goods is not there and the alternative of importing the required investment goods may be precluded by balance of payments difficulties;

2) The complementary inputs in terms of intermediate products, skills or market institutions may not be present;

3) The pressure on wage goods, especially food, may prevent the expansion of investment. The expansion of food production in turn may be limited partly by unavailability of the required inputs such as fertilizers, and partly for reasons of socio-economic institutions such as the lack of incentives due to pressure from landlords or money-lenders, absence of land reforms, etc.;

4) Difficulty of financing the required investment by additional savings or taxation. Savings may largely come from a corporate sector which may be foreign dominated so that the savings flow abroad; middle and upper class savers may not have sufficient confidence in domestic institutions and take their savings abroad; there may be no effective system of tax collection for lack of administrative capacity and lack of data; tax evasion may be uncontrollable. In such situations the increase in investment can only be financed by forced savings (inflation which is likely to be of an explosive character).

In all these directions, we encounter conditions of cumulative and circular causation frustrating the attempt to increase investment. For example, lack of physical capacity or foreign exchange may prevent the supply of fertilizers to farmers, while food shortages due to lack of fertilizers in turn will prevent the expansion of investment in fertilizer production. Where such conditions obtain the Harrod-Domar prescriptions of increasing the rate of investment will be of little practical use to developing countries. The solution must lie either in exogenous change (from aid, better export earnings, ample and cheaper financing, foreing investment, etc.); or else it must lie in improvements in the capital/output ratio, higher $X$-efficiency, development of the entrepreneurial spirit, improveded government policies, etc. The former path - improvement in exogenous conditions - is the path pursued by Keynes II, the Keynes of Bretton Woods. The latter path is the one pursued by Schumacher with his appropriate techonology, by Leibenstein with his X-efficiency, by Schumpeter with his entrepeneurs, and by the IMF with its emphasis on improved government policies. 
The difference between an industrial economy in depression - like the British economy of 1936 - and the situation in developing countries may be described in various ways all of which contain facets of the relevant difference. One way is to say that in the industrial economy with unemployment the problem is mainly one of demand management, to remedy a lack of effective demand, while in a developing country the problem is one of structural constraints on supply; hence the question is much more one of attacking supply bottlenecks than demand management. Another way of describing the difference is to say that in an industrial country the problem is cyclical and the policy task is to move the economy from an unemployment equilibrium to a full employment equilibrium, where as in developing countries the problem is structural and the policy task is to change the structure of the economy so that it becomes more responsive to stimulation. This second way of describing the difference also makes it clear that in a sense the policy task in developing countries is pre-Keynesian, namely in the sense that first the conditions must be created under which Keynesian policies could then become relevant and applied with chances of success. This is reminiscent of the thesis that what developing countries need in the first place is not just investment but pre-investment, in the sense of the technical assistance, $R \& D$, project design, pilot projects, training of people to operate projects, etc. $\left({ }^{14}\right)$ Translated from the micro-economic to the macro-economic level this means that before an expansion of investment can lead to the desired growth and fuller employment in developing countries, the pre-conditions in the sense of a more flexible and responsive economy first have to be created.

The third way of putting the difference is to say that in an industrial economy in recession and with unemployment it is possible by appropriate policies to create resources out of thin air as it were, since all the necessary resources are already latently present and only have to be given the kiss of life. In a developing country it is not possible to do this; the action required is much more real and in a sense much more micro than overall demand management. Keynes could rightly say that it could be justifiable even to dig holes and fill them up again, because of the indirect and multiplier effects of this useless activity; a developing country could not afford to tie up resources in a useless activity since this would preempt them from being available for the expanded investment which is the basis for the desired objective of growth. (However it may be quite justified to dig holes and fill them up again if this seems the only or best way of handing out food or income to idle people to keep them from starvation

(14) For the development of the concept of pre-investment see H.W. Singer, International Development, Growth and Change. McGraw-Hill, Chapter 2, "Towards a theory of pre-investmentn, pp. 18-25, 1964. 
- but food for work projects are not usually justified by such purely humanitarian reasons but are selected for their contribution to investment and growht as well.)

A fourth difference is that the Keynesian problem of moving from unemployment to full employment is of a short-term, cyclical and oncefor-all nature while the problems of development are of a long-term, structural and continuing nature. This also highlights the importance of technological capacity and of appropriate technology. Both of these could be taken for granted in the Keynesian analysis, and in any case the problem dealt with was a relatively short-term problem of moving the economy from unemployment to full employment; during this relatively short period technology could be assumed to remain constat. For developing countries, on the other hand, the problem is long-term - of dynamics rather than comparative statics - and the existence of appropriate technology cannot be taken for granted since the technology is essentially exogenous rather than endogenous.

Related to the essential domestic production of investment goods, there is also a clear example here of circular causation: the lack of endogenous appropriate technology prevents the domestic production of capital goods, while the lack of domestic production of capital goods and the need to import them from more advanced countries in its turn prevents the development of appropriate technology. For developing countries, with surplus labour but lacking capital and other complementary resources, the appropriate technology is clearly one which substitutes labour for capital, but the capability of substituting labour for capital requires technological power which is lacking. Moreover, the wide substitution of labour for capital makes food the ultimate "capital" good, and this in turn brings into play the structural constraints (both technological and human as well as socio-political) which stand in the way of increasing food production and obtaining larger marketed surpluses.

Yet another reason why the Keynesian model has only limited application to developing countries arises from the Harris-Todaro model of rural urban migration $\left({ }^{15}\right)$. The essence of this model is that the creation of additional modern sector urban jobs through increased aggregate demand is bound to attract additional migrants from rural areas. In the conditions typical of many developing countries, specially in Africa (where the Harris-Todaro model originated), urban wages are much higher than rural incomes and there is much underutilised and unutilised labour in the rural areas; in such conditions it can be assumed that for every urban job created by Keynesian policies there will be three, four or more rural migrants attracted into the urban areas - another multiplier, albeit of a

(15) J. R. HARRIS and M. P. TODARO - «Migration, Unemployment and Development: a two-sector Analysis», American Economic Review, March 1970. 
distinctly non-Keynesian or even anti-Keynesian type! Thus we would reach the paradoxical result that Keynesian policies would increase unemployment rather than reduce it - a case of having to run fast to stay in the same place. The capital resources of African countries would not be sufficient to pursue the Keynesian policies on such a scale and for long enough that the rural surplus labour is exhausted and the Keynesian model begins to apply. Moreover in this situation, as Arthur Lewis has shown, real wages would rise rapidly whereas the Keynesian model assumes that real wages can be kept down or cut in the process of expansion, at least in the short-term cyclical context. The Harris-Todaro model gives us an additional reason to those given by Lewis in his classical 1954 article on why the Keynesian model has severe limitations in poor economies with surplus labour.

Among the factors which Rao introduced as throwing doubt on the validity of Keynes for developing countries, the one which has become a continuing feature of subsequent discussion relates to the inelastic supply of food. Obviously the operation of the Keynesian multiplier where a rise in incomes leads to a simultaneous increase in savings and consumption must depend, in developing countries, crucially on additional supplies of food. In developing countries, a higher proportion of income increments will go into consumption, even though it may still be true that the marginal propensity to consume is lower than the average propensity. Moreover, at the low income levels of developing countries, much of the additional consumption will be in the form of demand for more food. But if food is produced by traditional small farmers - as could be assumed in India - who produce partly or largely for their own consumption, then an additional demand for food may lead to higher rural incomes which leads to greater self-consumption in the rural areas and may not result in any significant increase in marketable surpluses - or even a decrease (backward-bending supply curve). This will bring the expansion process to a grinding halt and result in inflation and intolerable balance of payments pressures if the attempt is made to follow expansionist Keynesian policies.

It is of interest to note that Rao's article was written two years before the creation of the big US Food Aid Programme under PL480. Subsequently in the late 50 s and early 60 s India became the recipient of a flood of US food aid which would have changed the picture which Rao painted. It has now become fashionable and conventional in development analysis to give top priority to breaking the food supply bottleneck by means of organizational change, technical progress, irrigation, etc. before the application of Keynesian policies can be contemplated with any chance of success. This priority applies specifically to the poorer developing countries who cannot hope to pay for food imports by exports of manufactures. The latter was of course the assumption which Keynes could make for the British economy of the 1930s when cheap food was available in unlimited quantities from the US and the British Commonwealth. 
It is of interest to compare Rao's arguments with those of Arthur Lewis in his famous article on "Economic Development with Unlimited Supplies of Labours which appeared two years after Rao in the Manchester School. Lewis also contrasts the Keynesian model with the different conditions in developing countries, and regretfully concludes (in the opening pages of his paper) that he must start from the classical model rather than from the Keynesian model, in spite of the superficially attractive analogy between DC unemployment and LDC unlimited supplies of labour. Like Rao, Lewis assumes that the Keynesian expansionist processes cannot operate in the traditional rural sector and do not apply to food production. But he does not derive the same pessimistic conclusion that the expansion process will be brought to a halt by food shortages and inflation or balance of payments crises, because he assumes that the transfer of surplus population to the rural areas will reduce the pressure of rural food consumption and set free the necessary marketable surpluses for the towns. In any case, in his model the expansionist process will not raise real incomes in the urban areas because of the competition for jobs from the unlimited rural surplus, so that contrary to Keynesian assumptions the marginal propensity to consume will not increase. This situation will change when the turning point has been reached and rural surplus labour is exhausted but by that time the development and industrialisation process is well established and the LDC has become a NIC and a potencial exporter of manufactures $\left({ }^{16}\right)$.

This predominant view, since the days of Rao and Lewis, that the nature of unemployment and indeed the whole nature of the economies of developing countries are sufficiently "different" from those of developed industrial countries with cyclical or even structural unemployment to require a "different" model is certainly well-founded. But there is one important qualification: if the additional investment can be specifically directed so as to eliminate production bottlenecks and increase elasticities of supply, and/or can be combined with aid or external investment to supply lacking complementary factors needed for expansion, the Keynesian model of self-financed development in which additional investment calls forth the additional savings required to finance it resumes its validity $\left({ }^{17}\right)$.

(16) LEWIS, W. A. - "Economic Development with Unlimited Supplies of Labour», Manchester School, 1954. The paraphrase of this paper given in the text is my own and Arthur Lewis must not be held responsible for it. His original paper has of course since been developed and modified in many different ways, both by himself and by others.

(17) This point is also made by A. P. Thirlwall (who has devoted much attention to the subject of this paper). In the most recent edition of his book on Growth and Development with Special Reference to Developing Economies he quotes credit for fertilisers, transport facilities, land settlement and irrigation as examples of such bottleneck-breaking investments, and quotes evidence from Ecuador and Morocco for high rates of return and short gestation periods for such investment. (Third edition, Macmillan, 1983, p. 274.) 
In the case of aid, food aid would be of special importance considering that an inelastic supply of food is one of the chief obstacles to the operation of Keynesian multiplier/accelerator types of expansion.

However, this restoration of the validity of the Keynesian model for developing countries is of somewhat limited relevance, because (a) it requires a high degree of fine-tuning, not only of the initial investment, but also of the subsequent expansion, to the specific bottlenecks in the economy which requires a degree of knowledge and information not normally available for developing countries' economies, and/or $(b)$ it requires external resources which is a departure from the self-contained Keynesian model for a national economy, and external resources which are equally fine-tuned to the key points among the obstacles to expansion.

It is interesting to note that Rao treats the increase in consumption of food producers - which prevents the Keynesian process - as a «dissipation". In the formal sense that is of course correct and in fact this increase in consumption by which the multiplier becomes "dissipated" can be treated as a "leakage" in the Keynesian sense. But viewed from another point of view, and specifically if the objective of development is seen as a reduction in poverty and the satisfaction of basic needs, this increase in rural consumption is of course a thoroughly desirable thing. A convinced Keynesian might say that if this is the end result of Keynesian policies, so be it. Moreover matters may not stop there; presumably the increased consumption of farmers will improve their health and productivity and make them more willing to accept organizational changes and try new techniques. This is a point which Rao fails to consider, and it leads to a more general point of some importance. In the Keynesian model, and in line with the situation in the advanced industrial countries, it is assumed that consumption does not affect the productivity of labour and hence investment; neither does the Harrod-Domar model. Yet as previously discussed, the idea of human investment which includes a productivity effect of improved nutrition may have considerable relevance for developing countries. If this is so the Keynesian process may be to that extent vindicated in its application to developing countries, although in an indirect way and in a way different to that of the General Theory itself.

The question of unutilized capacity in the consumption goods industries which is essential for the operation of Keynesian multipliers as complementary input to unemployed labour has also been the subject of considerable debate regarding its existence and nature in developing countries. There are three schools of thought which we can distinguish:

1) There is no unutilized capacity in developing countries, hence the multiplier cannot operate and you get vertical supply curves not only in food production but also in other sectors of the economy. That is the position of Rao; 
2) There is unutilized capacity but it is due to structural difficulties and specifically to foreign exchange shortages; these prevent the import of essential spare parts and combined with structural deficiencies and local skills in maintenance and manning this results in a significant proportion of manufacturing capacity being out of action at any given point of time. The effect of this is similar to the previous case: because of such production bottlenecks due to capital equipment being out of action supply curves become vertical and the multiplier cannot operate;

3) There is unutilized capacity which can be brought into operation by appropriate policies and development strategies. Paradoxically, this is the position both of the advocates of balanced growth and of unbalanced growth. In the case of balanced growth, the latent unutilized capacities can be brought into operation by simultaneous expansion of the different sectors of the economy providing the necessary complementary inputs for each other. In the case of unbalanced growth the latent complementary resources can be mobilized in a more microeconomic way, by applying the right incentives and mobilizing latent entrepreneurship for leading or key sectors of the economy which then blazes a trail for more general expansion (18). Under both strategies Keynesian processes, or rather something outwardly similar to them would apply in developing countries - provided of course that such strategies are feasible and can be successfully implemented. Outwardly similar only since in the Keynesian output the flexible element and all the resources required for expanding it towards ful employment levels are readily at hand; whereas in the developing countries expansion requires "strategies", "mobilization", "pressure mechanisms", "pacing devices" (all terms used by Hirschman) since the resources required are only latently or potentially required.

The mobilization of latent entrepreneurship is of course also a key feature of the Schumpeterian system where it is linket with innovation. In the Keynesian system innovation is external or exogeneous to the system. In fact Keynes' theory of falling marginal productivity of investment which led him to see the future of industrial countries in more leisure and arts rather than in higher incomes is clearly linked with what some would consider as his failure to build the dynamism of technology endogenously

(18) This position is broadly that of Hirschiman as is also indicated in his previously quoted essay on The Rise and Decline of Development Economics. 
into his system. There is no doubt that in developing countries improvement in technology, either through development of indigenous technology or through successful transfer or adaptation are key features in economic growth. To put it in the terms of Leibenstein $\left({ }^{19}\right)$, improvements in X-efficiency are an essential part of development process. Rather paradoxically, the Schumpeter/Hirschman/Leibenstein emphasis on innovation, technology and entrepreneurship, while it takes us outside the Keynesian system, yet at the same time it leads to the conclusion that the Keynesian expansion process has some, albeit modified applicability in developing countries. In other words, Keynes was relevant for developing countries in spite of his model rather than because of it.

We have discussed Rao's views about the relevance of Keynes to India. Much of the subsequent discussion has also related to India, sometimes with different results to Rao's $\left.{ }^{20}\right)$. While this is understandable in view of the strong links between the Indian academic tradition and Cambridge and the high degree of sophistication of Indian economists, the results can be misleading in the sense that India is not a typical developing country, as has been discussed before. It is noteworthy that Hla Myint, the Burmese economist, already complained about this exclusive concentration of the discussion on India in 1964 at the Manchester Conference on Teachig Development $\left({ }^{21}\right)$. It is quite true that at least in the theoretical literature there has been little direct discussion of the applicability of Keynes outside India. On the other hand as far as the international aspects are concerned, the Latin American school and the related Prebisch-Singer analysis of deteriorating terms of trade and unequal exchange is at least indirectly a refutation of the validity of Keynesian analysis to developing countries. It can be interpreted as stating that external factors prevent the successful application of domestic expansionist policies due to the resulting balance of payments pressures. Or to put it in Dudley Seers' terms, the proposition amounts to saying that there should be a separate model of countries relying on the export of primary products subject to deteriorating terms of trade and unequal exchange. But the policy prescription of ISI (import substituting industrialisation) amounts to an attempt to reconstitute the conditions in which Keynesian processes can function.

(19) LEIBENSTEIN, H. - "Allocative Efficiency Versus X-efficiency", American Economic Review, June 1966.

(20) The two most recent contributions are by S. Chakravarty, "Keynes, 'Classics' and the Developing Economies", and K. N. Raj, "Keynesian Economics and Agrian Economies", both in Reflections on Economic Development and Social Change. Essays in Honour of Professor V. K. R. V. Rao, editors C. H. Hanumantha Rao and P. C. Joshi, Allied Publishers Private Limited, New Delhi, 1979.

(21) MYINT, H. - "Economic Theory and the Underdeveloped Countries", in The Teaching of Development Economics, editors Kurt Martin and John Knapp, Frank Cass, London, 1967. 
In one sense the criticism of the General Theory being in terms of a closed economy and hence inapplicable - or even dangerours -- for developing countries because of their precariours balance of payments position is not fair to Keynes. It must be remembered that Keynes was firmly in favour of international commodity price stabilization. Professor Kaldor( $\left.{ }^{22}\right)$ has quite recently reminded us of Keynes' advocacy of buffer stocks in primary commodities in his article in The Economic Journal of $1938\left({ }^{23}\right)$. During the war Keynes did not only prepare his proposals for an International Clearing Union, but also for an agency for International Commodity Control which would set up buffer stocks for all the main commodities. This proposal was never properly acted upon although Keynes attributed the utmost importance to it. The subsequent negotiations for an International Trade Organisation (ITO) were only a pale shadow of what Keynes had intended and in any case they turned out to be futile since the US Congress did not ratify the ITO. It is clear that Keynes thought he could improve on the market mechanism not only in the macro-sense of maintaining full employment, but also in the micro sense of improving on the working of commodity markets. If the Keynesian system is mentally adjusted to include commodity price stabilization at a high and satisfactory level, thus guaranteeing profitable investment in primary commodity production, it certainly begins to look much more feasible and applicable to developing countries.

On top of all this there was, of course, in addition to the Keynes I of the General Theory, the Keynes II of Bretton Woods. If the removal of deflationary biases in the world economy, financial flows to developing countries and commodity price stabilization through buffer stocks - or even more reliably through a world currency based on a bundle of primary commodities such as Keynes wanted - are all assumed to have been achieved then the balance of payments objection to Keynesian policies looks distinctly weak.

The Keynes II of Bretton Woods also additionally was planning and pleading for an IMF which would have the power to put pressure on balance of payments surplus countries to take measures of adjustment in an expansionary direction. Instead of that we have an IMF which puts all the pressure for adjustment and "discipline" on the countries with balance of payments deficits, and in practice only on the developing countries. This is understandable because in the 25 ugolden years" of full employment with little inflation which foliowed on Bretton Woods there was no need to put expansionist pressures on balance of payments surplus coun-

(22) KALDOR, N. - "The Role of Commodity Prices in Economic Recovery", Lloyds Bank Review, July 1983, pp. 21-34.

(23) KEYNES, J. M. - «The Policy of Government Storage of Food Stuffs and Raw Materials", The Economic Journal, September 1938, pp. 449-460. 
tries; by the time this would have become right again we had got an IMF which in spite of the rhetoric of its charter was neither willing nor able to do so. In that sense the Keynesian system was hoist on the petard of its own success. But once again if we go through the mental exercise of imagining the existence of a Keynes II type IMF, expansionist policies in the developing countries would have become much more relevant and feasible.

In appreciating the importance of Keynes II -the Bretton Woods' Keynes - for developing countries we may return once again to Hirschman. In his essay $\left({ }^{24}\right)$ he suggests a second foundation-stone for development economics, in addition to the abandonment of mono-economics by Keynes $I$. This is the assertion of the mutual benefit claim, creating the possibility of international macro-economic interventions raising global welfare to a higher equilibrium level. Although Hirschman does not specifically mention Keynes in connection with this second foundation-stone, yet his role in proposing just such a global system inevitably comes to mind. One can argue whether Hirschman was right to include the assertion of the mutual benefit claim as a pre-condition for development economics, thus condemning all dependency school, unequal exchange, neo-Marxist, etc., thinking to an existence outside his defined boundaries of "development economics". However if one does accept this second pre-condition, then one is also bound to argue that Keynes played a crucial role in both these respects.

This paper has already given some examples of how the inclusion of Keynes II enables us to give a much more positive answer to the question of his relevance to developing countries. I think it is a tragedy that Keynes original ideas were not more fully accepted and did not prevail at Bretton Woods. I am thinking here particularly of his proposals for a world currency controlled to satisfy liquidity needs and based on primary commodities; the creation of an IMF imposing expansionary "discipline" on balance of payments surplus countries; but much less contractionary discipline on balance of payments deficit countries; the creation of an International Clearing Union which would automatically have worked in that direction; the creation of a full ITO etc. The Marshall Plan was a truly Keynesian measure and he would have acclaimed it but perhaps he would have seen that it would have been better if it had been slightly less generous, i. e. if it had exacted some repayment from such balance of payments surplus countries as Germany and Japan during the 1963-1973 decade, and if these repayments had then been channelled into developing countries with balance of payments deficits. Similarly if oil prices had been stabilized at a satisfactory level prior to 1973, the oil shock would not

(24) HIRSCHMAN, A. O. - "The Rise and Decline of Development Economics", loc. cit., 1982. 
have disrupted the system and measures to develop other energy resources and more oil resources would have been taken earlier and in good time. This is an imaginary reconstruction of the world as it could have been according to Keynes II, but it may perhaps serve as a testimony to the power of his thinking and to his ultimate relevance for developing countries.

But if we return more soberly to Keynes I, I cannot do better than quote the conclusion reached recently by Sukhamoy Chakravarty in his previously mentioned article $\left({ }^{25}\right)$ :

Keynes teaches us that given the problem of time and uncertainty, the job [of using surplus value constructively for development] is likely to be badly done by the market mechanism and the economy may remain caught in a low-level equilibrium unless an all-round and judicious investment effort is launched. It is, then, quite appropriate to conclude that the relevance of Keynes to developing countries is not merely methodological in nature, there are substantive economic insights as well which help us understand better the functioning of the economic mechanism in developing countries wherever a large number of investment decisions are made on a decentralized basis in an uncertain environment. While in some respects the classical model of development retains its primacy as a conceptual device, we understand this model much better including its merits and deficiences if we take full note of the contribution that Keynes made on fundamental questions of economic analysis, even though his policy preoccupations were quite different.

There is only one amendment I would make to this conclusion by Chakravarty. I would not agree that "the classical model of development retains its primacy». On this point I would go along with Dudley Seers. Our choice is wider than just between the classical model or the Keynesian model. Both are "Special Cases" and neither is fully relevant. What we need is "a conceptual device» or rather conceptual devices which are new and additional to both the classical and the Keynesian models. We have many elements of such a model available, and a number of them have been referred to in this paper. But they are still waiting for a synthesis which is a convincing and relevant as the Keynesian system was to the western industrial economies with unemployment and surplus capacity. Will there ever be a General Theory of Development? If so my own feeling

(25) CHAKRAVARTY, S. - "Keynes, 'Classics' and the Developing Economies", loc. cit., 1979 
is that it can only be built up from the many different Special Cases which Dudley Seers has talked about $\left({ }^{26}\right)$.

A distinction which we may make is between the precise assumptions and simplifications of the General Theory on the one hand and the way of thinking and concepts underlying its framework on the other $\left({ }^{27}\right)$. The former, the precise assumptions and simplifications, are broadly inappropriate for conditions in developing countries; the latter, the framework and concepts remain relevant, especially when we include the Keynes II of Bretton Woods. If he had had his way, the scope for better growth in the developing countries through increasing the rate of investment based on increasing effective demand for their products abroad would have been immensely greater than it is today. The relevance of Keynes $I$ is to a considerable degree a function of the acceptance of Keynes II.

(26) In an earlier paper dealing with a related subject, I have taken the same position in drawing a parallel between the universalism (Hirschman would call it mono-eonomics) of both the classical and Keynesian systems in speaking of an aggregate "investment" as the source of growth imperceptibly leading to a belief in a universally valid "efficient" or "modern" "superior" technology, versus the disaggregation of the investment concept into specific inputs leading to an emphasis on "appropriate" and indigenously developed or adapted technology. H.W. Singer, Keynesian Models of Economic Development and their Limitations: an Analysis in the Light of Gunnar Myrdal's 'Asian Drama'. U. N. Asian Institute for Economic Development and Planning, Occasional Papers, Bangkok, December 1969. Reprinted in H.W. Singer, The Strategy of Economic Development. Essays in the Economics of Backwardness, Macmillan, 1975, pp. 22-42.

(27) This distinction is very similar to the one made by John Fender, Understanding Keynes. An analysis of 'The General Theory', Wheatsheaf Books Ltd, 1981, pp. 149-150. Fender deals with the relevance of Keynes to current conditions in industrial countries but his distinction is equally valid when asking ourselves questions concerning his relevance to conditions in developing countries. 

mento

RESUMO:

Dedicado à memória de Dudley Seers, este artigo analisa o contributo de Keynes para a teoria do desenvolvimento, na sua generalização aos paises subdesenvolvidos actuais.

Para Hans Singer é fundamental distinguir entre Keynes I (antes de Bretton Woods) e Keynes II (depois de Bretton Woods).

O Keynes l, da Teoria Geral, trata do "caso especial» da Grä-Bretanha; as hipóteses em que assenta estão obviamente longe de poderem representar a realidade dos PVD.

É em Keynes II que é possivel encontrar um quadro conceptual alargado relevante quando à fundamentação de respostas para os problemas do desenvolvimento dos PVD.

Assim, a importância de Keynes I é, em grande medida, função do reconhecimento e aceitação de Keynes II.

\section{SINGER, H. W. - The importance of Keynes for developing countries}

\section{ABSTRACT:}

Dedicated to the memory of Dudley Seers, this articie analyses Keynes contribution to the theory of development, generally speaking in present-day underdeveloped countries.

For Hans Singer it is essential to distinguish between Keynes I (before Bretton Woods) and Keynes II (after Bretton Woods).

Keynes I, in his General Theory, deals with the "special case" of Great Britain; the hypotheses he lays down are obviously far from representing the reality of developing countries.

It is in Keynes II that it is possible to find a broad conceptual picture relevant to the bases of answers to the problems of the development of developing countries.

Therefore, the importance of Keynes I lies largely in the recognition and acceptance of Keynes II. 